\title{
Glutathione redox cycle dysregulation in Huntington's disease knock-in striatal cells
}

\author{
Márcio Ribeiro ${ }^{a}$, Tatiana R. Rosenstock ${ }^{a}$, Teresa Cunha-Oliveira ${ }^{a}$, Ildete L. Ferreira ${ }^{a}$, \\ Catarina R. Oliveira ${ }^{\mathrm{a}, \mathrm{b}}$, A. Cristina Rego ${ }^{\mathrm{a}, \mathrm{b}, *}$ \\ ${ }^{a}$ CNC-Center for Neuroscience and Cell Biology, University of Coimbra, Coimbra, Portugal \\ ${ }^{\mathrm{b}}$ Faculty of Medicine, University of Coimbra, Coimbra, Portugal
}

\section{A R T I C L E I N F O}

\section{Article history:}

Received 23 January 2012

Received in revised form

4 September 2012

Accepted 6 September 2012

Available online 14 September 2012

\section{Keywords:}

Huntington disease

Oxidative stress

Striatal cells

Reactive oxygen species

Huntingtin

\begin{abstract}
A B S T R A C T
Huntington's disease (HD) is a CAG repeat disorder affecting the HD gene, which encodes for huntingtin $(\mathrm{Htt})$ and is characterized by prominent cell death in the striatum. Oxidative stress was previously implicated in HD neurodegeneration, but the role of the major endogenous antioxidant system, the glutathione redox cycle, has been less studied following expression of full-length mutant Htt (FL-mHtt). Thus, in this work we analyzed the glutathione system in striatal cells derived from HD knock-in mice expressing mutant Htt versus wild-type cells. Mutant cells showed increased intracellular reactive oxygen species (ROS) and caspase- 3 activity, which were significantly prevented following treatment with glutathione ethyl ester. Interestingly, mutant cells exhibited an increase in intracellular levels of both reduced and oxidized forms of glutathione, and enhanced activities of glutathione peroxidase (GPx) and glutathione reductase (GRed). Furthermore, glutathione-S-transferase (GST) and $\gamma$-glutamyl transpeptidase $(\gamma-G T)$ activities were also increased in mutant cells. Nevertheless, glutamate-cysteine ligase (GCL) and glutathione synthetase (GS) activities and levels of GCL catalytic subunit were decreased in cells expressing FL-mHtt, highly suggesting decreased de novo synthesis of glutathione. Enhanced intracellular total glutathione, despite decreased synthesis, could be explained by decreased extracellular glutathione in mutant cells. This occurred concomitantly with decreased mRNA expression levels and activity of the multidrug resistance protein 1 (Mrp1), a transport protein that mediates cellular export of glutathione disulfide and glutathione conjugates. Additionally, inhibition of Mrp1 enhanced intracellular GSH in wild-type cells only. These data suggest that FL-mHtt affects the export of glutathione by decreasing the expression of Mrp1. Data further suggest that boosting of GSH-related antioxidant defense mechanisms induced by FL-mHtt is insufficient to counterbalance increased ROS formation and emergent apoptotic features in HD striatal cells.
\end{abstract}

(c) 2012 Elsevier Inc. All rights reserved.

\section{Introduction}

Huntington's disease (HD) is the most prevalent polyglutamine expansion disorder, characterized by motor and psychiatric disturbances and cognitive decline leading to dementia. HD is inherited in an autosomal dominant manner and fatal 15 to 20 years after the symptoms onset, which occur around the fourth decade of life in the majority of the patients [1]. The disease is caused by a CAG triplet expansion in exon 1 of the $H D$ gene, leading to an increase in the size of the polyglutamine tail at the $\mathrm{N}$-terminal of the huntingtin ( $\mathrm{Htt}$ ) protein [2]. Expression of mutant $\mathrm{Htt}(\mathrm{mHtt})$ causes striatal neurodegeneration and also affects the cerebral cortex later in the course of the disease [3].

\footnotetext{
* Corresponding author. Address: CNC-Center for Neuroscience and Cell Biology, and Faculty of Medicine, University of Coimbra, 3004-504 Coimbra, Portugal. Fax.: + 351239822776 .

E-mail addresses: arego@fmed.uc.pt, acrego@cnc.uc.pt, a.cristina.rego@gmail.com (A.C. Rego).
}

Oxidative stress is one of several dysfunctional mechanisms described in HD [4-8], which may result from impaired mitochondrial function, namely due to interaction of the organelle with $\mathrm{mHtt}[9]$ and/or imbalanced levels of antioxidants.

Altered oxidative parameters have been observed in both central and peripheral samples of HD patients and in some animal models of the disease. In HD postmortem tissues, levels of 8-hydroxydeoxyguanosine (8-OH-dG), a DNA oxidative damage marker, and malondialdehyde (MDA), a lipid peroxidation marker, were increased in caudate nucleus and parietal cortex $[4,10]$. In HD patients' blood plasma, elevated levels of $8-\mathrm{OH}-\mathrm{dG}$ were observed [8,11]. Also, increased levels of 8-OH-dG [8] and MDA [6] were previously observed, respectively, in leukocytes and serum of HD patients. Concordantly, in R6/2 HD mice (expressing exon 1 of the human $H D$ gene), 8-OH-dG levels were shown to be increased in striatum, urine, and plasma [12].

The levels of antioxidants also vary depending on the type of tissue and possibly the stage of HD pathology. In striatum and cortex of HD postmortem samples a proteomic analysis revealed 
an induction of antioxidant proteins peroxiredoxin 1,2, and 6 and glutathione peroxidase (GPX) 1 and 6, and an increase in superoxide dismutase (SOD)2 (Mn-SOD) and catalase activities, when compared to control individuals [13]. Furthermore, increases in mRNA levels of GPx1, catalase, and SOD1 ( $\mathrm{Cu} / \mathrm{Zn}-\mathrm{SOD})$ were observed in striatal cells expressing full-length $\mathrm{mHtt}$ (FL-mHtt) [14]; however, these studies did not analyze the enzymatic activities of the antioxidant systems. Conversely, in erythrocytes from HD patients, GPx and SOD1 activities were found to be decreased, compared to unaffected subjects [8], suggesting an impairment of the antioxidant defenses in HD peripheral samples.

Concordantly with increased levels of antioxidant proteins in HD human brain, a significant increase in the levels of the reduced form of glutathione (GSH) was observed in striatum of 8- to 12week-old R6/2 HD mice [15]. Enhanced GSH levels were also detected in isolated mitochondria from both cortex and striatum of R6/2 HD mice; however, glutamate-cysteine ligase (GCL), an enzyme involved in the synthesis of GSH, was reported to be actively decreased in both striatum and cortex of R6/2 HD mice, not explaining the increase in GSH levels [16]. Moreover, in the same study, glucose-6-phosphate dehydrogenase (G6PD) activity, an enzyme that produces NADPH essential for glutathione reductase (GRed) activity, was also reported to be decreased in the striatum of R6/2 HD mice [16]. Together, these observations show some discrepancies in the antioxidant redox systems in HD, namely associated with the glutathione redox cycle, evidencing the need to clarify the regulation of antioxidant levels in striatal cells expressing FL-mHtt. Thus, in this study, we detailed the changes in the GSH antioxidant system in striatal cells derived from HD knock-in mice. Our results indicate that expression of FL-mHtt is accompanied by a heightening of GSH-related antioxidant levels and activity due to reduced expression and functional activity of multidrug resistance protein 1 (Mrp1). Nevertheless, increased antioxidant activity appears to be insufficient, as HD cells exhibit increased reactive oxygen species (ROS) generation and cell death features.

\section{Materials and methods}

\section{Materials}

Dulbecco's modified Eagle's medium (DMEM), fetal bovine serum (FBS), penicillin/streptomycin, and geneticin were purchased by GIBCO (Paisley, UK). ATP, DL-dithiothreitol (DTT), NEM (N-ethylmaleimide), NDA (2,3-naphthalenedicarboxaldehyde), maleimide, $\gamma$-Glu-Cys, L-glutamic acid, L-glutamine, OPA (o-phthaldialdehyde), PMSF (phenylmethanesulfonyl fluoride), protease inhibitors (chymostatin, pepstatin, A, leupeptin, and antipain), glucose-6phosphate, $\gamma$-glutamylcysteine $(\gamma-G C)$, reduced glutathione (GSH), oxidized glutathione or glutathione disulfide (GSSG), glutathione reductase, NADP, NADPH, tert-butyl hydroperoxide, glutathione reduced ethyl ester (GSHee), glutathione-S-transferase (GST) assay kit, glycylglycine, 5-sulfosalicylic acid dihydrate, calcein-AM, 5-(3-(2-(7-chloroquinolin-2-yl)ethenyl)phenyl)-8-dimethylcarbamyl4,6 -dithiaoctanoic acid (MK-571) sodium salt, and anti- $\beta$-actin were from Sigma Chemical Co. (St. Louis, MO, USA). Anti-glutathione reductase (GRed) and anti-glutamate-cysteine ligase catalytic (GCLc) subunits were from Abcam (Cambridge, UK). Enhanced ChemiFluorescence reagent (ECF), anti-rabbit IgG (from goat), and anti-mouse IgG + IgM (from goat) were from GE Healthcare (Little Chalfort, UK). The fluorescence probe $2^{\prime}, 7^{\prime}$-dichlorodihydrofluorescein diacetate $\left(\mathrm{H}_{2} \mathrm{DCFDA}\right)$ and Trizol reagent were obtained from Molecular Probes/Invitrogen (Eugene, OR, USA). Ac-DEVD-AFC was obtained from Calbiochem/Merck Chemicals (Darmstadt, Germany). $\gamma$-Glutamyl-7-amino-4-methyl-coumarin ( $\gamma$-glutamyl-AMC) was purchased from Bachem (Bubendorf, Switzerland). First Strand cDNA Synthesis Kit (AMV) was purchased from Roche (Mannheim, Germany). GoTaq Flexi DNA polymerase (5x kit) and dNTP Mix were from Promega (Madison, WI, USA).

\section{Cell culture}

Striatal cells expressing wild-type Htt (STHdh $h^{\mathrm{Q} 7 / \mathrm{Q} 7}$ or wildtype cells; clone 2aA5) or homozygous mutant cells derived from knock-in mice, expressing FL-mHtt with 111 glutamines (STHdh $h^{\mathrm{Q} 111 / \mathrm{Q} 111}$ cells; clone 109-1A), were kindly donated by Dr. Marcy E. MacDonald (Department of Neurology, Massachusetts General Hospital, Boston, MA, USA). Cells were maintained in an incubation chamber at $33{ }^{\circ} \mathrm{C}$ with $5 \% \mathrm{CO}_{2}$, in DMEM culture medium supplemented with 10\% FBS, $2 \mathrm{mM}$ glutamine, $1 \%$ penicillin/streptomycin, and $400 \mu \mathrm{g} / \mathrm{ml}$ geneticin (G-418), as described previously [17]. Striatal cells were plated on multiwell chambers or flasks at a density of $0.06 \times 10^{6}$ cells $/ \mathrm{cm}^{2} 48 \mathrm{~h}$ before the experiments in order to allow the desired confluence. In some experiments, cells were incubated with GSH ethyl ester (GSHee, at $0.05,0.25$, or $1 \mathrm{mM}$ ) or $50 \mu \mathrm{M} \mathrm{MK}-571$, for $24 \mathrm{~h}$.

\section{Preparation of mitochondrial-enriched fractions}

Striatal cells were washed twice in PBS, lysed, and scraped $\left(4{ }^{\circ} \mathrm{C}\right.$ ) in a sucrose buffer (in $\mathrm{mM}: 250$ sucrose, 20 Hepes/KOH (pH 7.5), $100 \mathrm{KCl}, 1.5 \mathrm{MgCl}_{2}, 1$ EGTA, and 1 EDTA) supplemented with $1 \mathrm{mM}$ DTT, $100 \mu \mathrm{M}$ PMSF, and $1 \mu \mathrm{g} / \mathrm{ml}$ protease inhibitors (chymostatin, pepstatin A, leupeptin, and antipain). Cell lysates were then homogenized with a potter (120 strokes) and centrifuged at $560 \mathrm{~g}$ for $12 \mathrm{~min}$ at $4{ }^{\circ} \mathrm{C}$. The pellet (nuclei and cell debris) was discarded and the supernatant was centrifuged at $12,000 \mathrm{~g}$ for $20 \mathrm{~min}$ at $4{ }^{\circ} \mathrm{C}$ to obtain a mitochondrial-enriched pellet. The mitochondrial fraction was further resuspended in a supplemented sucrose buffer, and protein levels were determined using the Bio-Rad protein assay (Bradford method). The mitochondrialenriched fractions were used for analysis of glutathione reduced and oxidized form levels, and GRed, GPx, and GST activities.

\section{Intracellular ROS measurements}

After brief washing with PBS, striatal cells were incubated for $30 \mathrm{~min}$ with $20 \mu \mathrm{M} \mathrm{H} \mathrm{H}_{2}$ DCFDA, a stable nonfluorescent cellpermeable compound, at $33^{\circ} \mathrm{C}$, in modified Krebs medium (in mM: $135 \mathrm{NaCl}, 5 \mathrm{KCl}, 0.4 \mathrm{KH}_{2} \mathrm{PO}_{4}, 1.8 \mathrm{CaCl}_{2}, 1 \mathrm{MgSO}_{4}$ 20 Hepes, and 5.5 glucose) at $\mathrm{pH}$ 7.4. $\mathrm{H}_{2}$ DCFDA is incorporated by the cells and hydrolyzed by esterases to form $\mathrm{H}_{2} \mathrm{DCF}$, which is converted to DCF by intracellular peroxides [18]. Intracellular levels of peroxides were measured by following DCF fluorescence (488 nm excitation, $530 \mathrm{~nm}$ emission) at $33^{\circ} \mathrm{C}$, continuously, for $1 \mathrm{~h}$, using a Gemini EM microplate spectrofluorometer (Molecular Devices, USA). In order to correct the DCF fluorescence, values for variations in total intracellular protein content in each well were quantified by the Bio-Rad protein assay (Bradford method). The values were obtained as RFU (relative fluorescence units) per minute per milligram protein for each condition and then expressed as percentage of wild-type cells.

\section{Measurement of caspase-3 activity}

Caspase-3 activity was determined using a fluorimetric substrate Ac-DEVD-AFC. The DEVD sequence is cleaved by caspase-3 releasing the fluorogenic AFC which is quantified by fluorimetry. Striatal cells were washed twice with PBS and then lysed at $4{ }^{\circ} \mathrm{C}$ with a lysis buffer composed of (in $\mathrm{mM}$ ): 25 Hepes, $2 \mathrm{MgCl}_{2}$, 1 EDTA, 1 EGTA, supplemented with $1 \mathrm{mM}$ DTT, $100 \mu \mathrm{M}$ PMSF, 
$1 \mu \mathrm{g} / \mathrm{ml}$ protease inhibitors (chymostatin, pepstatin A, leupeptin, and antipain) and $0.04 \%$ Triton X-100 ( $\mathrm{pH} 7.5$ ). After scraping, a reaction buffer composed of $25 \mathrm{mM}$ Hepes, $10 \%$ sucrose, $0.1 \%$ Chaps, 2 mM DTT, and $15 \mu \mathrm{M}$ Ac-DEVD-AFC (pH 7.5) was added to the cell samples. The fluorescence was monitored for $1 \mathrm{~h}$ at $33{ }^{\circ} \mathrm{C}$ with excitation at $400 \mathrm{~nm}$ and emission at $505 \mathrm{~nm}$. After the readings, the samples were used to determine the amount of protein per well. The values were obtained as RFU per minute per milligram protein for each condition and then expressed as percentage of wild-type cells.

\section{Measurement of glutathione levels by fluorimetry}

The cells were washed twice in PBS and lysed in $15 \mathrm{mM}$ Tris, $\mathrm{pH} 7.4$, and the intracellular levels of reduced and oxidized glutathione (GSH and GSSG, respectively) were determined using a fluorimetric assay, according to a previously described method [19]. GSH levels were measured in samples after the addition of ortho-phthaldialdehyde (1 mg OPA/ml methanol) and $100 \mathrm{mM}$ $\mathrm{NaH}_{2} \mathrm{PO}_{4}$. After $15 \mathrm{~min}$ incubation, the fluorescence was measured using an excitation wavelength of $350 \mathrm{~nm}$ and an emission wavelength of $420 \mathrm{~nm}$. The experimental procedure for GSSG was similar, although the samples were mixed for 30 min with $\mathrm{N}$-ethylmaleimide (5 mg NEM/ml methanol) which forms adducts with GSH. Then, the mixture was incubated for $15 \mathrm{~min}$ in $100 \mathrm{mM}$ $\mathrm{NaOH}$ plus OPA ( $1 \mathrm{mg}$ OPA $/ \mathrm{ml}$ methanol), and the fluorescence was measured with excitation at $350 \mathrm{~nm}$ and emission at $420 \mathrm{~nm}$ in a Gemini EM microplate spectrofluorometer (Molecular Devices, USA). The results were calculated as RFU per milligram protein and expressed as percentage of wild-type cells or as a percentage of control (untreated) conditions in the case of MK-571 incubation.

\section{Measurement of GPx and GRed activities}

The cells were washed twice in PBS and lysed in $25 \mathrm{mM}$ Tris- $\mathrm{HCl}(\mathrm{pH} \mathrm{7.4)}$ and then centrifuged at $20,800 \mathrm{~g}$ for $10 \mathrm{~min}$, at $4{ }^{\circ} \mathrm{C}$ (Eppendorf Centrifuge 5417R). The supernatant was used for protein quantification using the Bio-Rad protein assay (Bradford method) and for measuring GRed and GPx activities, spectrophotometrically, at $340 \mathrm{~nm}$, through the analysis of NADPH oxidation, as described previously [20] with some modifications. Briefly, the activity of GPx in samples was measured on a 5 min incubation, in the dark, with phosphate buffer containing $0.25 \mathrm{M} \mathrm{KH}_{2} \mathrm{PO}_{4}, 0.25 \mathrm{M} \mathrm{K}_{2} \mathrm{HPO}_{4}$, and 0.5 mM EDTA, pH 7.0, $10 \mathrm{mM}$ $\mathrm{GSH}$, and GRed (1 unit). The reaction occurred after the addition of $2.5 \mathrm{mM}$ NADPH and $12 \mathrm{mM}$ tert-butyl hydroperoxide. For the activity of GRed, each sample was incubated with a phosphate buffer containing $0.2 \mathrm{M} \mathrm{K}_{2} \mathrm{HPO}_{4}$ and $2 \mathrm{mM}$ EDTA, pH 7.0, plus $2 \mathrm{mM}$ NADPH. The measurements were initiated with the addition of $20 \mathrm{mM}$ GSSG. GRed and GPx activities were determined using a SpectraMax Plus ${ }^{384}$ microplate spectrophotometer (Molecular Devices, USA). Results were calculated as milliunits (mU) per milligram protein and expressed as percentage of wild-type cells.

\section{Measurement of G6PD and 6PGD activities}

Glucose-6-phosphate dehydrogenase (G6PD) activity was determined according to Choo and collaborators [16], with some minor modifications. Briefly, the cells were washed twice in PBS and lysed in $25 \mathrm{mM}$ Tris- $\mathrm{HCl}(\mathrm{pH} 7.4)$ and then centrifuged at $20,800 \mathrm{~g}$ for $10 \mathrm{~min}$, at $4{ }^{\circ} \mathrm{C}$ (Eppendorf Centrifuge 5417R). The supernatant was used for protein quantification using the Bio-Rad protein assay (Bradford method) and cell samples (30 $\mu \mathrm{g})$ were mixed with a reaction buffer containing (in $\mathrm{mM}$ ): 0.38 NADP,
6.3 $\mathrm{MgCl}_{2}, 3.3$ glucose-6-phosphate, and 5 maleimide (an inhibitor of 6-phosphogluconate dehydrogenase (6PGD) activity) in $50 \mathrm{mM}$ Tris- $\mathrm{HCl}$ ( $\mathrm{pH}$ 7.5). For 6PGD activity determination, experiments were performed in the absence of maleimide, corresponding, therefore, to the total NADPH production (G6PD+ 6PGD) by the pentose phosphate pathway; thus 6PGD activity $=$ total NADPH production - G6PD activity. The NADPH production was continuously monitored at $340 \mathrm{~nm}$ using a SpectraMax Plus $^{384}$ microplate spectrophotometer (Molecular Devices, USA) at $37^{\circ} \mathrm{C}$ and the results were calculated as milliunits (mU) per milligram protein and expressed as percentage of wild-type cells.

\section{Determination of GCL and GS activities}

GCL and glutathione synthetase (GS) activities were measured according to White and collaborators [21], with some minor modifications [22]. Cells were washed twice with PBS and lysed with $25 \mathrm{mM}$ Tris- $\mathrm{HCl}$ (pH 7.4) plus $0.1 \mathrm{mM}$ EDTA. Cellular extracts were centrifuged at $20,800 \mathrm{~g}$ for $10 \mathrm{~min}$ at $4{ }^{\circ} \mathrm{C}$, and protein content was analyzed by the Bio-Rad protein assay (Bradford method). For GCL activity, $50 \mu \mathrm{l}$ of sample was added to $50 \mu \mathrm{l}$ of GCL reaction buffer containing (in $\mathrm{mM}$ ): 100 Tris, 10 ATP, 20 L-glutamic acid, 2 EDTA, 20 sodium borate, 2 serine, and $40 \mathrm{MgCl}_{2}$, and incubated at $37{ }^{\circ} \mathrm{C}$ for $5 \mathrm{~min}$. The GCL reaction was initiated by adding $50 \mu \mathrm{l}$ of $2 \mathrm{mM}$ L-cysteine. For GS activity, L-glutamic acid and L-cysteine were replaced with $30 \mathrm{mM}$ glycine and $3 \mathrm{mM} \gamma$-glutamylcysteine $(\gamma-\mathrm{GC})$, respectively. After $20 \mathrm{~min}$ incubation, the GCL and GS reactions were stopped by adding $50 \mu \mathrm{l}$ of $200 \mathrm{mM} 5$-sulfosalicylic acid. Samples were vortexed, incubated on ice for $20 \mathrm{~min}$, and centrifuged at $660 \mathrm{~g}$ at $4{ }^{\circ} \mathrm{C}$, for $5 \mathrm{~min}$. Then, $20 \mu \mathrm{l}$ of supernatant was transferred into a 96-well plate and $180 \mu \mathrm{l}$ of 2,3-naphthalenedicarboxaldehyde (NDA) derivatization solution (50 mM Tris, $\mathrm{pH} 10,0.5 \mathrm{M} \mathrm{NaOH}$, and $10 \mathrm{mM}$ NDA in DMSO, $\mathrm{v} / \mathrm{v} / \mathrm{v} 1.4 / 0.2 / 0.2$, respectively) was then added to each well to form NDA- $\gamma$-GC or NDA-GSH fluorescent complexes. The fluorescence was detected at $472 \mathrm{~nm}$ excitation and $528 \mathrm{~nm}$ emission, using a Gemini EM microplate spectrofluorometer (Molecular Devices, USA). The results were calculated as RFU per milligram protein and expressed as percentage of wild-type cells.

\section{Measurement of glutathione-S-transferase activity}

Determination of GST activity was performed accordingly to the manual provided by the GST assay kit (Sigma). Briefly, after a washing step in PBS, cell samples were mixed in a 96-well plate with a substrate solution containing 1-chloro-2,4-dinitrobenzene (CDNB) and GSH and the absorbance was followed at $340 \mathrm{~nm}$ for $6 \mathrm{~min}$. The results were calculated in micromoles per minute per milligram protein and expressed as percentage of wild-type cells.

\section{Measurement of $\gamma$-glutamyl transpeptidase activity}

The cells were lysed at $4{ }^{\circ} \mathrm{C}$ in $100 \mathrm{mM}$ Tris-HCl, $1 \mathrm{mM}$ EDTA, and $0.1 \%$ Triton X-100; pH 7.6; and $\gamma$-glutamyl transpeptidase $(\gamma-\mathrm{GT})$ activity was measured according to Zhu and collaborators [22] with some modifications. Briefly, $50 \mu \mathrm{l}$ of cell samples was added to $50 \mu \mathrm{l}$ of a reaction mixture containing $100 \mathrm{mM}$ Tris- $\mathrm{HCl}$ (pH 7.6), $40 \mathrm{mM}$ glycylglycine, $40 \mu \mathrm{M} \gamma$-glutamyl-7-amino4-methyl-coumarin ( $\gamma$-glutamyl-AMC), and $0.1 \%(\mathrm{v} / \mathrm{v})$ Triton $\mathrm{X}-100$, in a 96 -well plate. The fluorescence was measured with excitation at $370 \mathrm{~nm}$ and emission at $440 \mathrm{~nm}$, for $45 \mathrm{~min}$ at $33^{\circ} \mathrm{C}$. The values were obtained as RFU per minute per milligram protein for each condition and then expressed as percentage of wild-type cells. 
Measurement of intra- and extracellular levels of total glutathione by HPLC

Extracellular cultured medium was collected, whereas the cells were washed with PBS and further lysed in $1 \mathrm{M} \mathrm{NaOH}$ for determination of intra- and extracellular levels of total glutathione (GSH+GSSG). Both fractions were centrifuged at $20,800 \mathrm{~g}$, at $4{ }^{\circ} \mathrm{C}$ for $10 \mathrm{~min}$, to remove cell debris, and the supernatants were used for total glutathione analysis in a Gilson-ASTED HPLC system. Samples were separated on a Hichrom ACE-type column $(150 \times$ $4.6 \mathrm{~mm}, 5 \mu \mathrm{M} \mathrm{C} 18$ ) at a flow rate of $2.5 \mathrm{ml} / \mathrm{min}$ for $45 \mathrm{~min}$, using a ternary solvent system consisting of solvent A [37.5 mM sodium phosphate, $50 \mathrm{mM}$ propionic acid, $7 \%$ acetonitrile, and 3\% dimethyl sulfoxide ( $\mathrm{pH} 6.2$ )], solvent B ( $40 \%$ acetonitrile, $33 \%$ methanol, and $7 \%$ dimethyl sulfoxide), and solvent C [ $62.5 \mathrm{mM}$ sodium phosphate, $50 \mathrm{mM}$ propionic acid, 7\% acetonitrile, and 3\% dimethyl sulfoxide ( $\mathrm{pH}$ 5.5)]. Total glutathione was detected as a fluorescent derivative after precolumn derivatization with $o$-phthaldialdehyde/ 2-mercaptoethanol (OPA/MCE), using a Gilson Model 121 fluorescent detector, with excitation at $340 \mathrm{~nm}$ and emission at $410 \mathrm{~nm}$. Total glutathione levels were determined by comparison with peak areas of GSH standards, calculated in nanomoles per milligram protein and expressed as a percentage of wild-type cells. Protein levels were determined by the Bio-Rad protein assay (Bradford method).

\section{Analysis of Mrp1 activity based on calcein fluorescence}

Mrp1 activity was determined based on calcein fluorescence, since Mrp1 is involved in the transport of calcein to the extracellular space [23]. Striatal cells were cultured for $24 \mathrm{~h}$ and then briefly washed in PBS. After the washing step, the cells were incubated with $5 \mu \mathrm{M}$ calcein-AM in modified Krebs medium for $1 \mathrm{~h}$, at $33^{\circ} \mathrm{C}$. Calcein-AM diffuses into cells where it is cleaved by intracellular esterases, resulting in fluorescent calcein. After incubation, striatal cells were washed twice in PBS and intracellular calcein fluorescence was analyzed using excitation at $494 \mathrm{~nm}$ and emission at $517 \mathrm{~nm}$. The results were calculated as RFU per milligram protein and expressed as a percentage of wild-type cells.

\section{Western blotting}

Striatal cells were washed twice in PBS and extracted in lysis buffer containing (in $\mathrm{mM}$ ): 20 Tris- $\mathrm{HCl}$ ( $\mathrm{pH} \mathrm{7}$ ), $100 \mathrm{NaCl}, 2$ EDTA, 2 EGTA, supplemented with $0.1 \mathrm{mM}$ PMSF, 1\% Triton X-100 and $1 \mu \mathrm{g} / \mathrm{ml}$ protease inhibitors (antipain, chymostatin, leupeptin, and pepstatin A). Total extracts were centrifuged at 20,800g for 10 min in order to discard debris, and protein content was determined by the Bio-Rad protein assay (Bradford method). Samples were denatured in $50 \mathrm{mM}$ Tris- $\mathrm{HCl}, \mathrm{pH} 6.8$, containing $2 \%$ sodium dodecyl sulfate (SDS), $5 \%$ glycerol, $0.01 \%$ bromophenol blue, and $100 \mathrm{mM}$ DTT at $95{ }^{\circ} \mathrm{C}$, for $5 \mathrm{~min}$. Thirty micrograms of protein was separated on a $12 \%$ SDS-PAGE and electroblotted onto polyvinylidene difluoride (PVDF) membranes. The membranes were further blocked with 5\% fat-free milk and incubated overnight with anti-GRed (1:2000), anti-GCL $(1: 1000)$, or anti- $\beta$-actin $(1: 10,000)$, used as loading control. Immunoreactive bands were developed with ECF reagent, which is converted into a fluorescent compound by alkaline phosphatase associated with the secondary antibodies, and visualized using a Bio-Rad Versa Doc 3000 Imaging System.

\section{Total RNA extraction and reverse transcriptase}

RNA from different samples was obtained with Trizol reagent according to the manufacturer's protocol. Briefly, striatal cells were lysed and homogenized with Trizol. The RNA was precipitated with isopropyl alcohol and the final pellet was resuspended with water DEPC (diethylpyrocarbonate) at $0.01 \%(\mathrm{v} / \mathrm{v})$. Before performing reverse-transcriptase PCR (RT-PCR), the quality of RNA was verified through an electrophoresis in 1\% agarose gel to check the ribosomal RNA subunits $18 \mathrm{~S}$ and $28 \mathrm{~S}$. Then, the samples were incubated at $65{ }^{\circ} \mathrm{C}$ for $15 \mathrm{~min}$, to avoid extensive secondary structure that may interfere with the annealing step and then were chilled on ice for $5 \mathrm{~min}$. The concentration of RNA was measured and $1 \mu \mathrm{g}$ was used in each reaction to obtain the cDNA. RNA was transcribed into cDNA in a template-primer mix using the First Strand cDNA Synthesis Kit (AMV) (Roche, Mannheim, Germany). The reaction was as follows: $+25^{\circ} \mathrm{C}$ for $10 \mathrm{~min}$ and $+42{ }^{\circ} \mathrm{C}$ for $60 \mathrm{~min}$, for primer annealing and cDNA synthesis, respectively, $+99^{\circ} \mathrm{C}$ for $5 \mathrm{~min}$, for the denaturation of reverse transcriptase, and then the samples were cooled to $+4{ }^{\circ} \mathrm{C}$ for $5 \mathrm{~min}$.

\section{Quantification of mRNA levels of G6PD and Mrp1}

The concentration of the resulting single-stranded cDNA was determined, and $10 \mathrm{ng}$ was used to perform PCR to G6PD and Mrp1. The cDNA of each sample was amplified using sequencespecific primers to G6PD, forward ( $\left.5^{\prime}-3^{\prime}\right)$ ATG GCA GAG CAG GTG GCC, reverse $\left(5^{\prime}-3^{\prime}\right)$ GCA CTG TTG GTG GAA GAT G; and to Mrp1, forward $\left(5^{\prime}-3^{\prime}\right)$ CTG CAC AAC CTG CGC TTC, reverse $\left(5^{\prime}-3^{\prime}\right)$ GGT GCC AGA GGC CAG AC. The normalization of the amplified product was performed in relation to the product of actin obtained in the same samples using as primers $\left(5^{\prime}-3^{\prime}\right)$ GGA GAC GGG GTC ACC CAC AC and (5'-3') AGC CTC AGG GCA TCG GAA CC, forward and reverse, respectively. All the reactions were performed using GoTaq Flexi DNA polymerase (5x kit) and dNTP mix $10 \mathrm{mM}$. The amplification reaction mixture $(50 \mu \mathrm{l})$ contained $10 \mu \mathrm{l}$ of the cDNA template, $1.5 \mathrm{mM} \mathrm{MgCl}_{2}, 0.2 \mu \mathrm{M}$ of each primer, $0.05 \mathrm{U}$ Taq polymerase. The thermal cycling conditions were $3 \mathrm{~min}$ at $94{ }^{\circ} \mathrm{C}$, proceeding with 40 cycles of $94^{\circ} \mathrm{C}$ for $30 \mathrm{~s}$, $57{ }^{\circ} \mathrm{C}$ for $30 \mathrm{~s}$, and $72{ }^{\circ} \mathrm{C}$ for $45 \mathrm{~s}$, followed by $72{ }^{\circ} \mathrm{C}$ for $10 \mathrm{~min}$. The PCR products were visualized in $1.7 \%$ agarose gel and afterward analyzed using a Bio-Rad Gel Doc 3000 Imaging System. The results were presented as mRNA G6PD levels in relation to actin.

\section{Statistical analysis}

Statistical significance was determined by Student's $t$ test for comparison between two Gaussian populations, or by two-way ANOVA followed by the Bonferroni post test for analysis of multiple groups, as described in the figure legends. Data were expressed as the mean \pm SEM of the number of experiments indicated in the figure legends. Significance was accepted at $P<0.05$.

\section{Results}

ROS production and caspase-3 activation in HD striatal mutant cells-influence of GSHee

In order to investigate ROS production in HD striatal cells derived from knock-in mice, we used the fluorescent probe $\mathrm{H}_{2}$ DCFDA which has been reported to measure hydroperoxides, including $\mathrm{H}_{2} \mathrm{O}_{2}$, $\mathrm{ONOO}^{-}$, and hypochlorous acid $(\mathrm{HOCl})$ in viable cells $[18,24]$ A significant increase in ROS formation was observed in mutant cells when compared to wild-type cells (Fig. 1A). Treatment with GSHee, a cell-permeable ester of GSH $(0.05,0.25$, and $1 \mathrm{mM})$, significantly decreased ROS levels in mutant cells to similar values of wild-type (control) cells (Fig. 1A). Moreover, an increase in caspase-3 activity was observed in mutant cells (Fig. 1B), which might be related to the increase in ROS formation, as described previously by us [1]. GSHee treatment also decreased caspase-3 
A

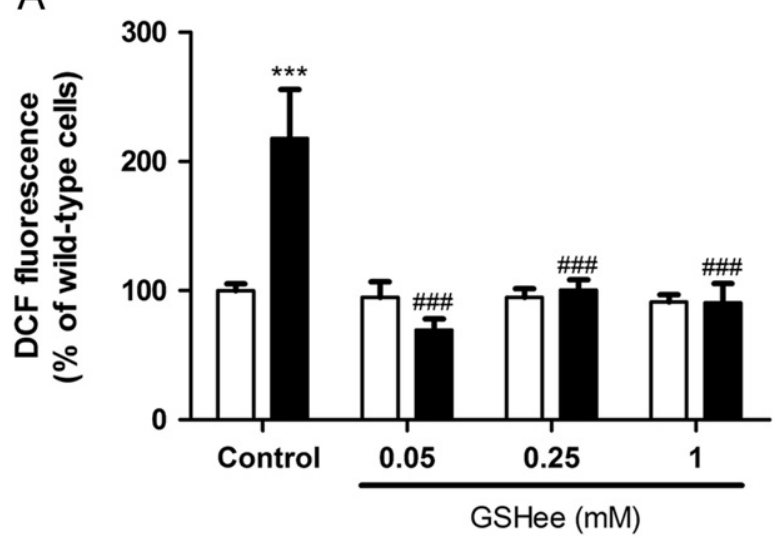

B

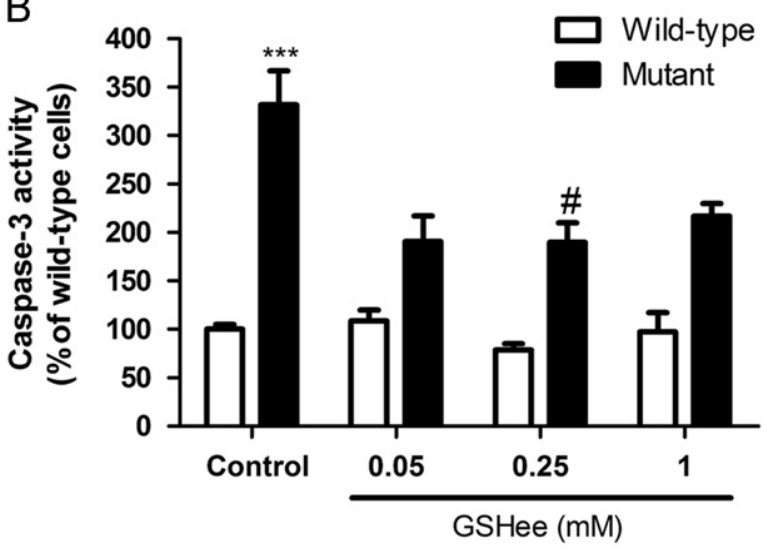

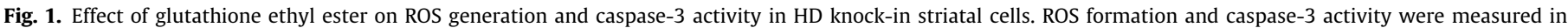

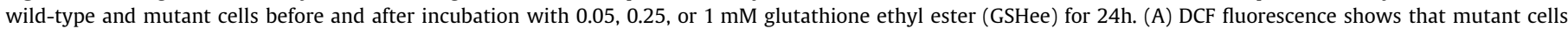

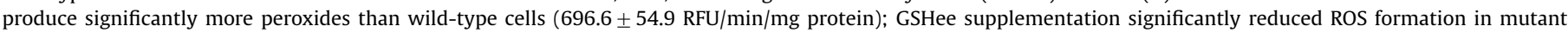

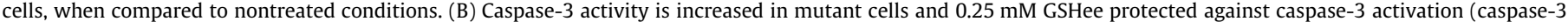

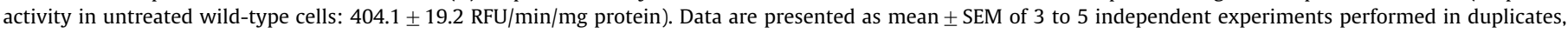

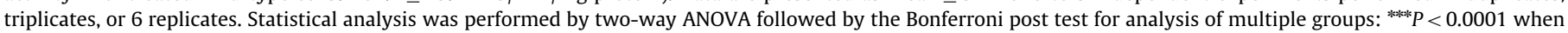
compared to wild-type cells; ${ }^{\#} P<0.05$ and ${ }^{\# \# \# ~} P<0.0001$ when compared to nontreated conditions.

activity in mutant cells (Fig. 1B), which was significant for $0.25 \mathrm{mM}$ GSHee. These results suggested that intracellular levels of the reduced form of glutathione (GSH) might be insufficient to deal with ROS produced in cells expressing mHtt. Thus, in the following experiments we determined the changes in components of the glutathione redox cycle in HD striatal cells.

\section{Glutathione redox cycle Is affected on expression of mutant huntingtin}

GSH has been shown to be essential to detoxify cells against $\mathrm{H}_{2} \mathrm{O}_{2}$. In order to investigate the levels of the glutathione antioxidant defense systems present in striatal mutant and wild-type cells, we measured the intracellular levels of GSH and GSSG. Surprisingly, a significant increase in the levels of GSH (Fig. 2A and B) and GSSG (Fig. 2C and D) was found in total (cellular) and mitochondrial fractions of mutant cells, compared to wild-type cells. Taking into account that both metabolites increased, the GSH/GSSG ratio was not significantly changed in mutant versus wild-type cells, in both cellular (GSH/GSSG ratio in wild-type cells: $7.42 \pm 2.3$ ) and mitochondrial (GSH/GSSG ratio in wild-type mitochondria: $6.2 \pm 2.1$ ) fractions.

An increased intracellular pool of both GSH and GSSG suggested an alteration of the glutathione redox cycle enzymes in HD knockin striatal cells. Thus, we further determined GPx and GRed activities. GPX converts GSH and $\mathrm{H}_{2} \mathrm{O}_{2}$ into GSSG and $\mathrm{H}_{2} \mathrm{O}$, respectively. GRed uses GSSG and NADPH to produce GSH and NADP ${ }^{+}$. Concomitant with the alterations in GSH and GSSG, we observed a significant increase in total and mitochondrial GPx activity in mutant cells, when compared to wild-type cells (Fig. 2E and F). Moreover, we observed that total and mitochondrial GRed activities were increased in mutant cells, as compared to wild-type cells (Fig. 2G and H). Altered GRed activity was not accounted for by differences in protein expression levels between mutant and wildtype cells, as determined by Western blotting (supplementary Fig. S1). Analysis of GPx protein levels by Western blotting was unsuccessful using two different antibodies to GPX-1.

NADPH and pentose-phosphate NADPH-producing enzymes are increased in mutant cells

In order to explain the increase in activity of GRed in mutant cells we further measured the activities of the pentose phosphate pathway enzymes, which are mainly responsible for producing the NADPH necessary for GRed activity, namely G6PD and 6PGD. Our results showed significant increases in G6PD and in 6PGD activities in HD mutant cells, compared to wild-type cells (Fig. 3A and $\mathrm{B}$ ), corroborating our previous findings. However, no changes in mRNA levels of G6PD were found in striatal cells (Fig. 3C). Moreover, we observed significantly higher levels of NADPH (by about 2-fold) in mutant cells (data not shown).

Decreased GSH-producing enzymes and increased activities of $\gamma$ glutamyl transpeptidase and glutathione-S-transferase in mutant cells

Because increased glutathione levels could result from increased GSH synthesis, we also studied GCL and glutathione synthetase (GS) activities and analyzed the protein expression levels of GCL catalytic subunit (GCLc). Unexpectedly, we observed a significant decrease in GCL and GS activities in mutant cells, compared to wild-type cells (Fig. 4A and B), suggesting decreased GSH synthesis. We also observed a slight, although significant, decrease in the protein levels of GCLc in mutant cells when compared to wild-type cells (Fig. 4C), contributing to the observed decrease in GCL activity (Fig. 4A). Since these results did not explain the higher GSH levels observed in Fig. 2A and B, we measured the activities of $\gamma-\mathrm{GT}$, an enzyme involved in GSH degradation, and GST, which also participates in glutathione metabolism. Our results demonstrate an increase in the activity of $\gamma-\mathrm{GT}$ in mutant cells when compared to wild-type cells (Fig. 5A). Moreover, GST activity was also increased in total and mitochondrial (although not significant) fractions obtained from mutant cells, compared to wild-type cells (Fig. 5B and C), thus not explaining the intracellular accumulation of GSH.

Decreased extracellular glutathione levels and Mrp1 mRNA levels on expression of mutant huntingtin

In order to explain the higher levels of GSH in mutant cells, we also evaluated the levels of glutathione by HPLC, which gives information about total glutathione (GSH plus GSSG) levels. Concordantly with data shown in Fig. 2, we observed a significant increase in the intracellular total glutathione levels in mutant cells (Fig. 6A). Because the activities of GSH metabolizing and 
A

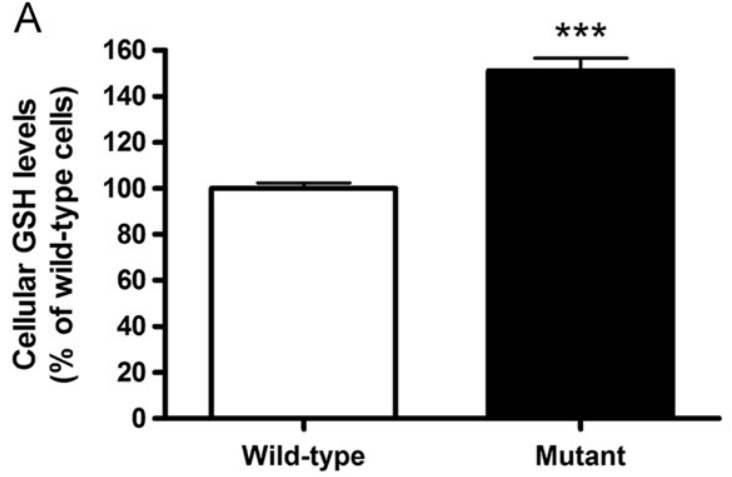

C

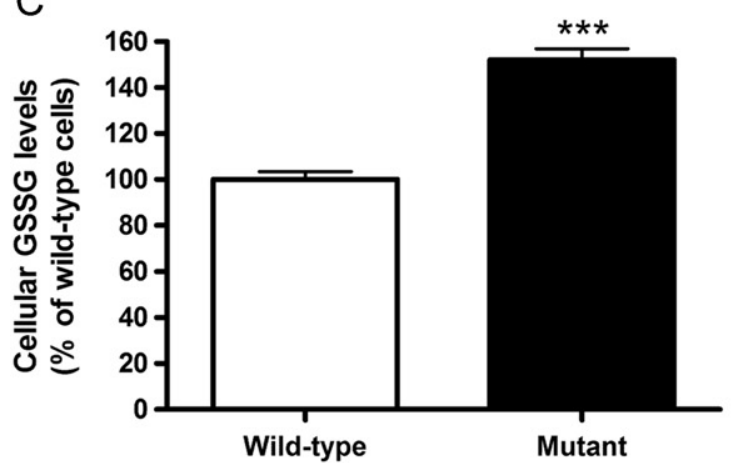

E

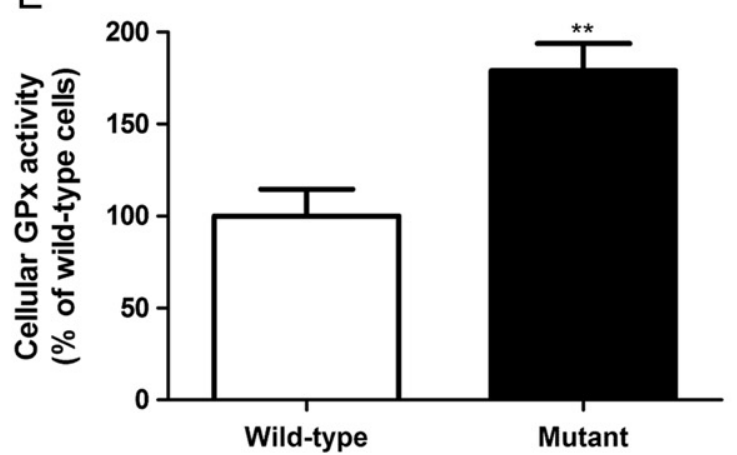

G

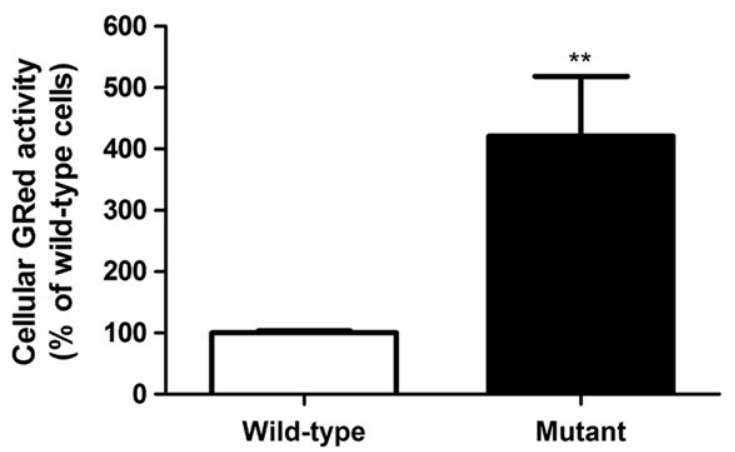

B

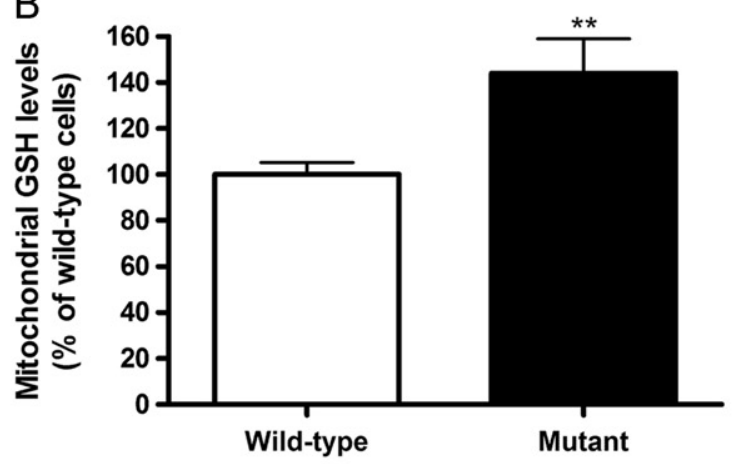

$\mathrm{D}$

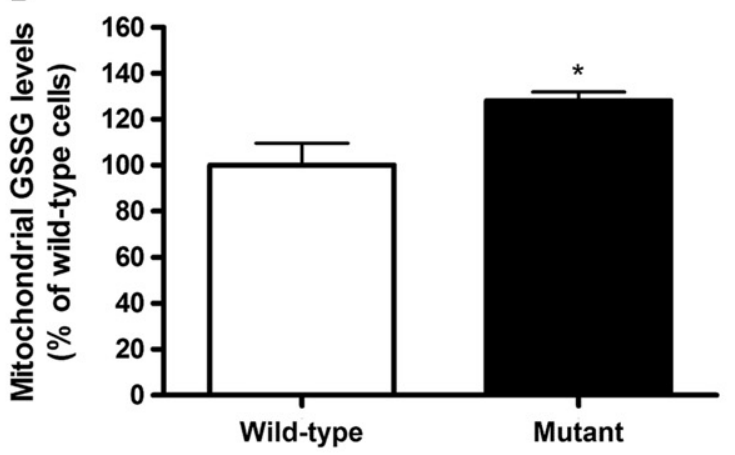

$\mathrm{F}$

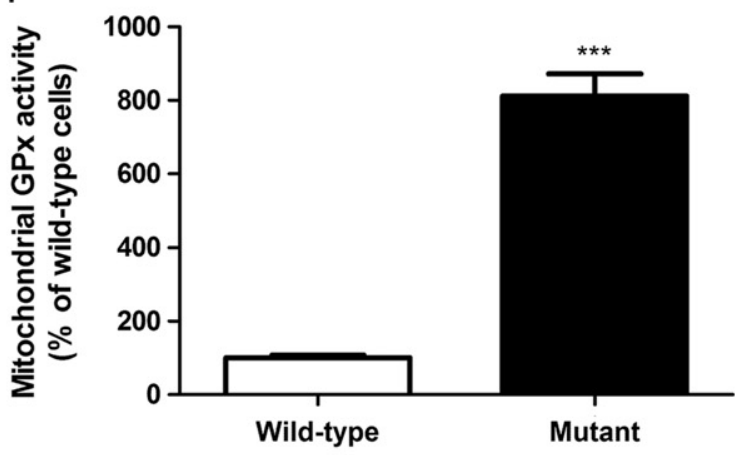

$\mathrm{H}$

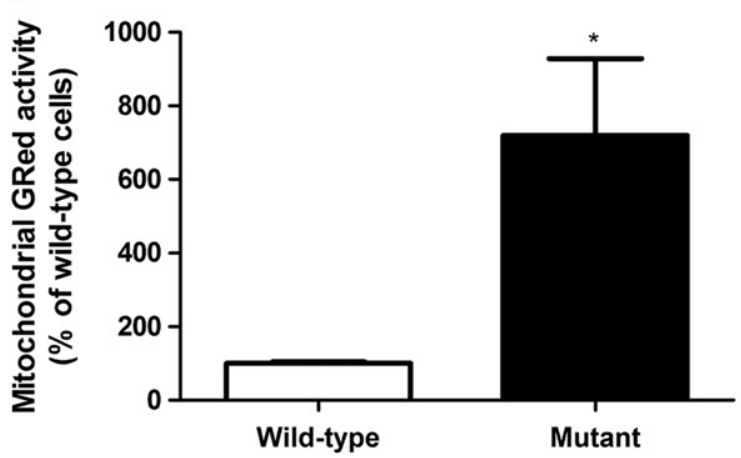

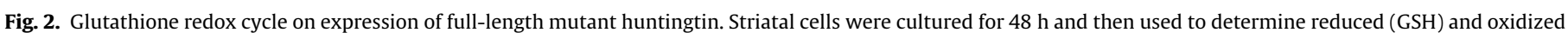

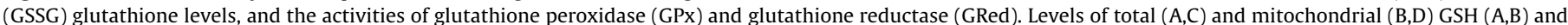

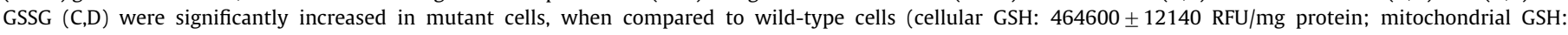

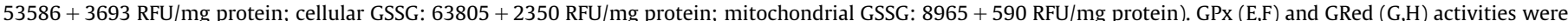

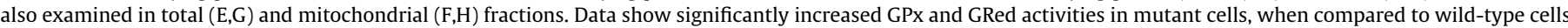

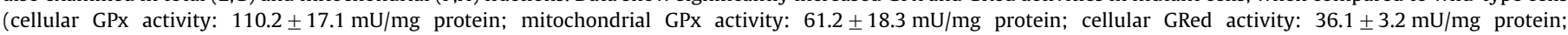

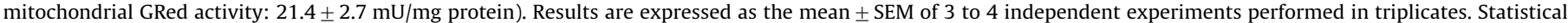
analysis was performed by Student's $t$ test: ${ }^{*} P<0.05$; ${ }^{* *} P<0.01$ and ${ }^{* * *} P<0.0001$ when compared to wild-type cells.

converting enzymes, $\gamma$-GT and GST, were increased (Fig. 5), the rise in GSH in mutant cells was still unexplained. Thus, we analyzed whether an enhanced intracellular GSH pool resulted from cellular retention by evaluating the extracellular levels of total glutathione in the culture medium of striatal cells maintained for $72 \mathrm{~h}$ in culture. Data in Fig. 6B show a slight, but 
A

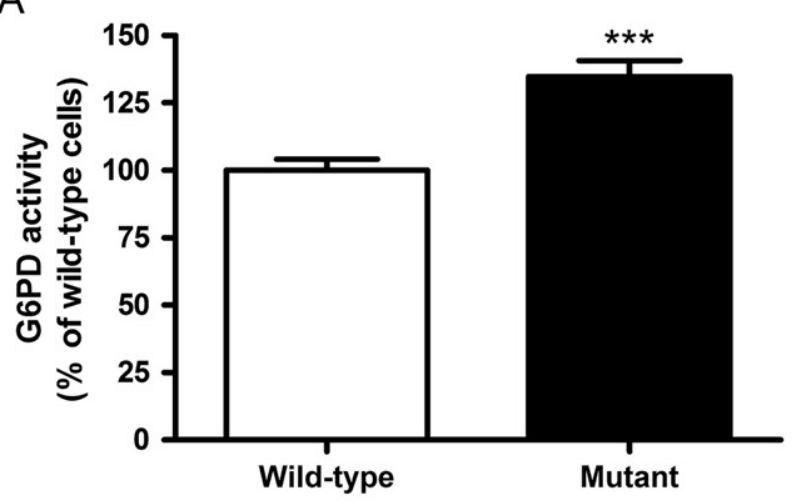

B

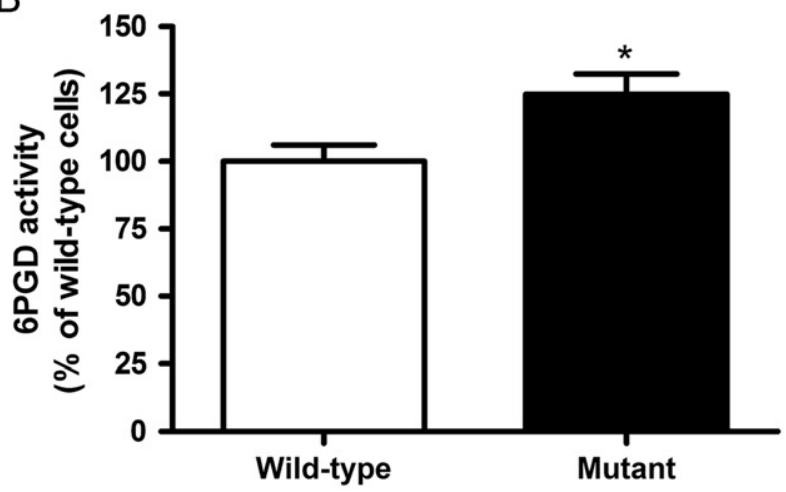

C
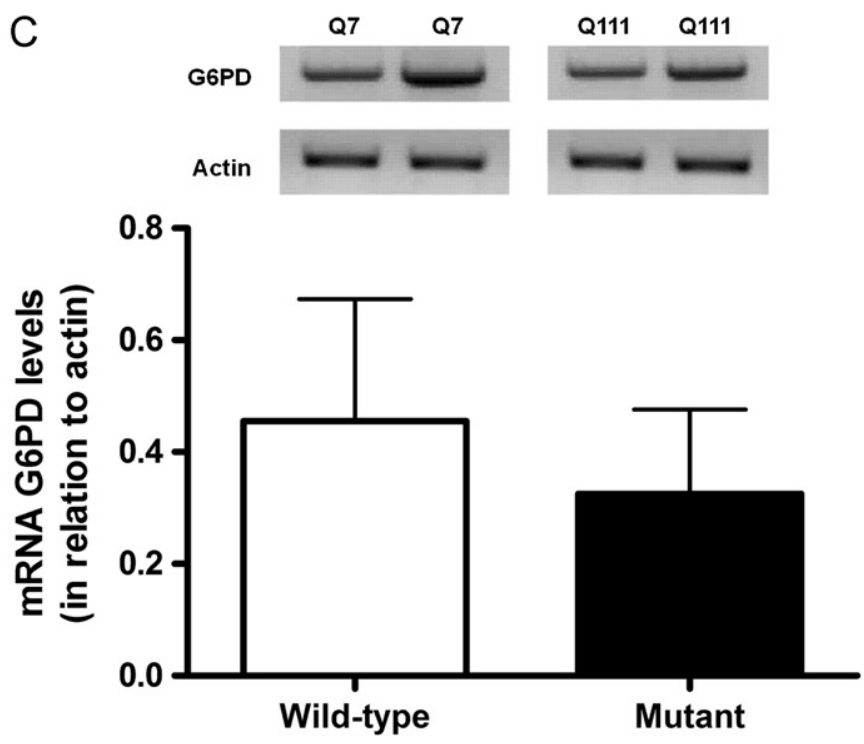

Fig. 3. NADPH-producing pentose phosphate pathway enzyme activities in striatal mutant cells. HD mutant striatal cells from knock-in mice and wild-type cells were used for analysis of glucose 6-phosphate dehydrogenase (G6PD), 6-phosphogluconate dehydrogenase (6PGD) activities, and G6PD mRNA levels. G6PD (A) and 6PGD (B) activities were significantly increased in mutant cells, when compared to wild-type cells, whereas G6PD mRNA levels (C) were unchanged in mutant cells (G6PD activity in wild-type cells: $89.4 \pm 11.2 \mathrm{mU} / \mathrm{mg}$ protein; 6PGD activity in wild-type cells: $52.3 \pm 10.1 \mathrm{mU} / \mathrm{mg}$ protein). The results are expressed as the mean \pm SEM from 3 to 4 independent experiments performed in triplicates. Statistical analysis was performed by Student's $t$ test: ${ }^{*} P<0.05$ and **** $P<0.0001$ when compared to wild-type cells.

significant, decrease in the accumulation of extracellular total glutathione (about $8 \%$ decrement of GSH plus GSSG levels present in the culture medium, containing FBS) in the mutant striatal cells, suggesting a deficit in its release.
A

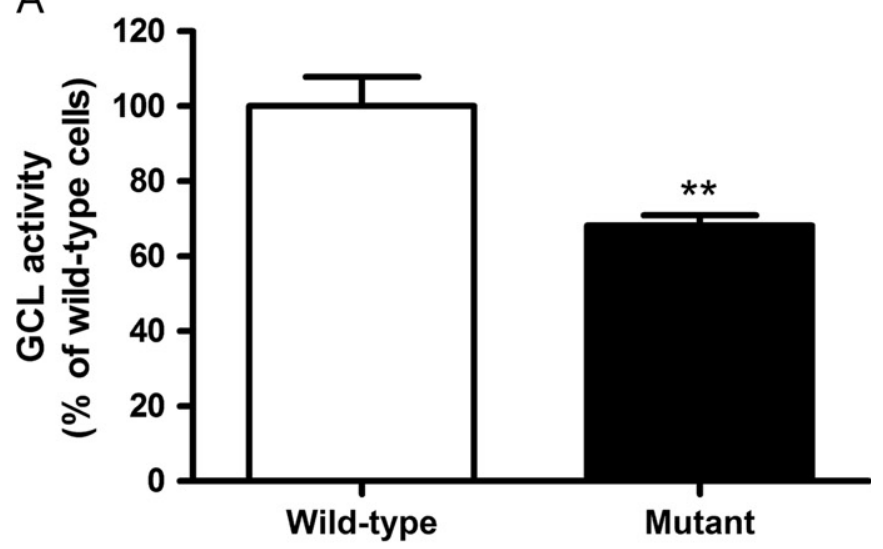

B

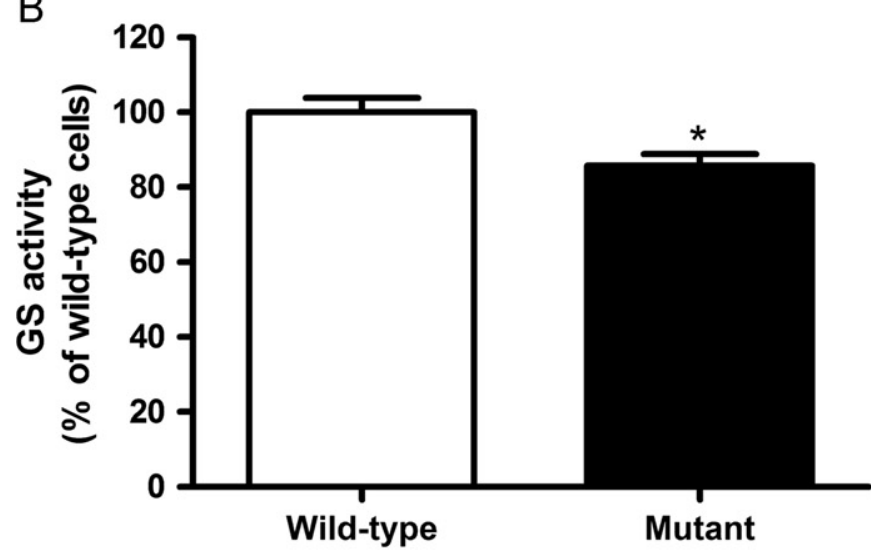

C

GCLc

$73 \mathrm{kDa}$ $\beta$-actin

$42 \mathrm{kDa}$

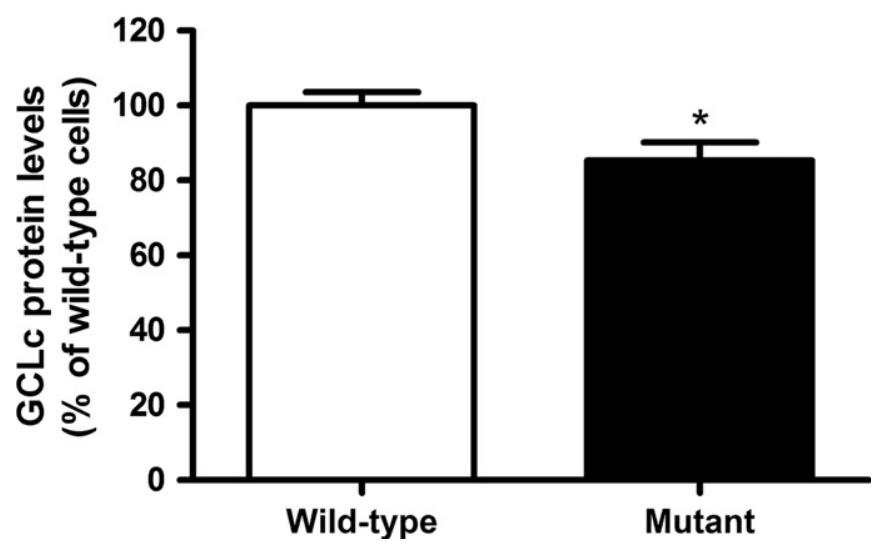

Fig. 4. Activity and protein expression levels of enzymes involved in GSH synthesis in mutant cells. GSH synthesis was determined through the analysis of (A) glutamatecysteine ligase (GCL) and (B) glutathione synthetase (GS) activities, and (C) catalytic subunit of GCL (GCLc) protein levels, which were decreased in mutant versus wildtype cells (GCL activity: $3981 \pm 138.4 \mathrm{RFU} / \mathrm{mg}$ protein; GS activity: $5764 \pm 223.7 \mathrm{RFU} /$ $\mathrm{mg}$ protein).The results are expressed as the mean \pm SEM from 3 to 6 independent experiments performed in duplicates. Statistical analysis was performed by Student's $t$ test: ${ }^{*} P<0.05$ or ${ }^{* *} P<0.01$ when compared to wild-type cells.

In order to explain the decrease in glutathione release we determined the mRNA expression of Mrp1, a transport protein that mediates cellular export of glutathione and glutathione conjugates (e.g., [25]). Importantly, Mrp1 expression was largely and significantly 
A
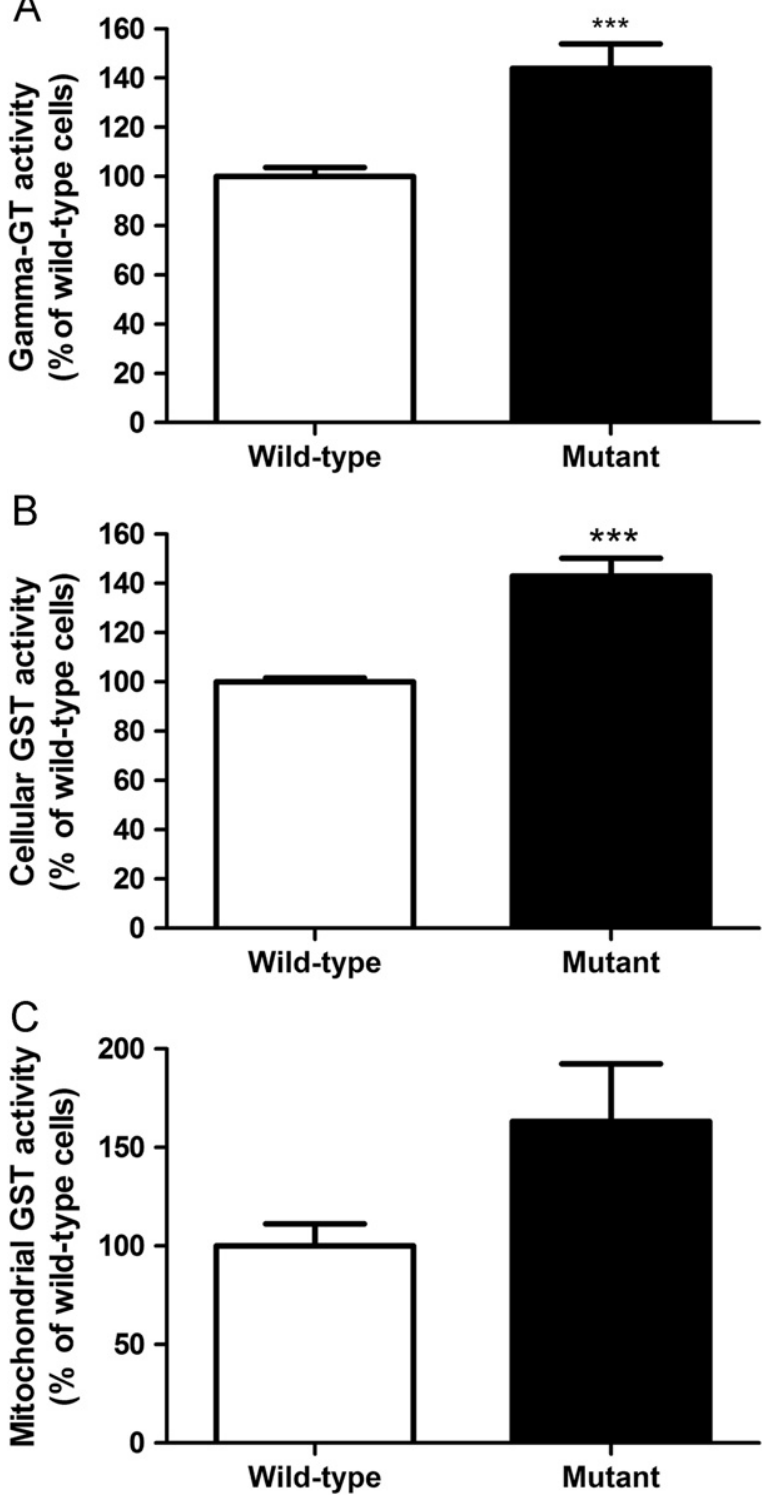

Fig. 5. Activities of gamma-glutamyltranspeptidase and glutathione-S-transferase in HD knock-in striatal cells. Gamma-glutamyl transpeptidase $(\gamma-G T)(A)$ and glutathione-S-transferase (GST) $(B, C)$ were measured in total lysates $(A, B)$ and mitochondrial fractions (C) obtained from HD mutant and wild-type striatal cells. $\gamma$-GT and GST activities were increased in mutant cells when compared to wildtype cells, although statistically significant results compared to wild-type cells were observed in total fractions only $(\gamma-$ GT activity in wild-type cells: $372 \pm 29.5$ $\mathrm{RFU} / \mathrm{min} / \mathrm{mg}$ protein; cellular and mitochondrial GST activity in wild-type cells: $78.2 \pm 5.6 \mu \mathrm{mol} / \mathrm{min} / \mathrm{mg}$ protein and $42.4 \pm 2.3 \mu \mathrm{mol} / \mathrm{min} / \mathrm{mg}$ protein, respectively). The results are expressed as the mean \pm SEM from 3 independent experiments performed in duplicates. Statistical analysis was performed by Student's $t$ test: ${ }^{* * * *} P<0.0001$ when compared to wild-type cells.

decreased in mutant cells (Fig. 6C), suggesting that expression of FLmHtt induces alterations in the glutathione dynamics due to altered expression of Mrp1. This result was supported by a significant increase in intracellular GSH levels in wild-type cells after Mrp1 inhibition with MK-571 (at $50 \mu \mathrm{M}$, for $24 \mathrm{~h}$ ), whereas no changes were detected in mutant cells (Fig. 6D). Additionally, we determined the activity of Mrp1 based on the fluorescence of calcein. Mrp1 is involved in the cellular export of calcein and therefore an increase in calcein fluorescence may correlate with decreased Mrp1 activity [23]. In accordance with decreased expression of the protein, a significant increase in intracellular calcein fluorescence was observed in mutant cells, when compared to wild-type cells, indicating a decrease in Mrp1 activity (Fig. 6E).

\section{Discussion}

In this work we found evidence for oxidative stress in striatal cells expressing FL-mHtt and thus more closely mimicking the genetic expression of mHtt. Increased ROS occurs concomitantly with enhanced intracellular glutathione levels and activity of the glutathione redox cycle, despite the downward effects of mHtt on the activity and expression of enzymes involved in GSH synthesis. Importantly, decreased expression and activity of Mrp1 favor the intracellular accumulation of glutathione.

Previous studies reported significantly higher ROS formation in the striatum of R6/1 HD mice expressing exon $1 \mathrm{of} \mathrm{mHtt}$, compared to control mice [26]. In HD knock-in striatal cells, mitochondrial dysfunction [27-29] may be related to increased formation of superoxide (author's unpublished data) and other cellular ROS, as shown in this study. Moreover, in Wistar rats subjected to the mitochondrial complex II inhibitor 3-nitropropionic acid (3-NP), known to mimic some characteristics of $\mathrm{HD}$, higher peroxide formation was detected when compared to untreated rats [30]. Although HD knock-in striatal cells evidence increased ROS generation, they do not exhibit massive cell death and large or visible $\mathrm{mHtt}$ aggregates [17], thus mimicking initial HD cytopathological features. Nevertheless, these cells exhibit features of apoptosis, as demonstrated by increased caspase-3 activation [14,31].

We further show that striatal cells expressing FL-mHtt present higher levels of GSH compared to wild-type cells, although this is not sufficient for preventing the rise in ROS. Indeed, treatment with GSHee was effective in preventing ROS generation, revealing that mutant cells are under a reversible state of oxidation. Also, caspase- 3 activation was ameliorated by treatment of mutant striatal cells with GSHee, further suggesting that increased intracellular accumulation of GSH is insufficient to rescue HD cells from features of apoptotic cell death. Previously, treatment of HD striatal cells with GSHee significantly prevented a 3-NPmediated decrease in mitochondrial membrane potential [32].

Although HD knock-in striatal cells showed increased levels of glutathione, a decrease in GSH levels was previously described in the cortex of HD patients [33]. In addition, decreased GSH levels and higher lipid peroxidation were observed in the plasma of HD symptomatic and asymptomatic individuals, compared to ageand sex-matched controls, suggesting that oxidative stress may occur before the onset of HD symptoms [34]. Conversely, the levels of mitochondrial GSH were increased in the striatum and cortex of R6/2 HD mice compared to wild-type animals, suggesting a compensatory mechanism to counteract the increase in mitochondrial ROS generation [16], which may also help to explain our data. Despite this common result, the R6/2 mice present a rapid progression of the disease and some phenotypes not typically associated with HD [1], and thus considerably differ from models expressing FL-mHtt.

Despite increased intracellular glutathione, here we demonstrate, for the first time, a decrease in GCL and GS activities in striatal cell lines expressing FL-mHtt, largely suggesting a decrease in GSH synthesis. Additionally, GCLc protein (Fig. 4C) and mRNA (author's unpublished data) expression levels are significantly decreased in mutant cells. In agreement, a decrease in GCL activity was previously shown in the cortex and striatum of R6/2 HD, compared to wild-type mice [16]. In the present work we show that this defect is also observed following expression of FL-mHtt.

Along with increased cellular GSH in HD striatal cells, we observed an increase in GSSG levels. In contrast, a significant decrease in GSSG (by about 50\%) was detected in the caudate nucleus of HD patients [35]. We also observed an increase in GPx activity. In accordance with these data, GPx1 transcription levels were shown to be increased in three clones of striatal cells expressing mHtt, compared to wild-type cells [14]. Nevertheless, 
A
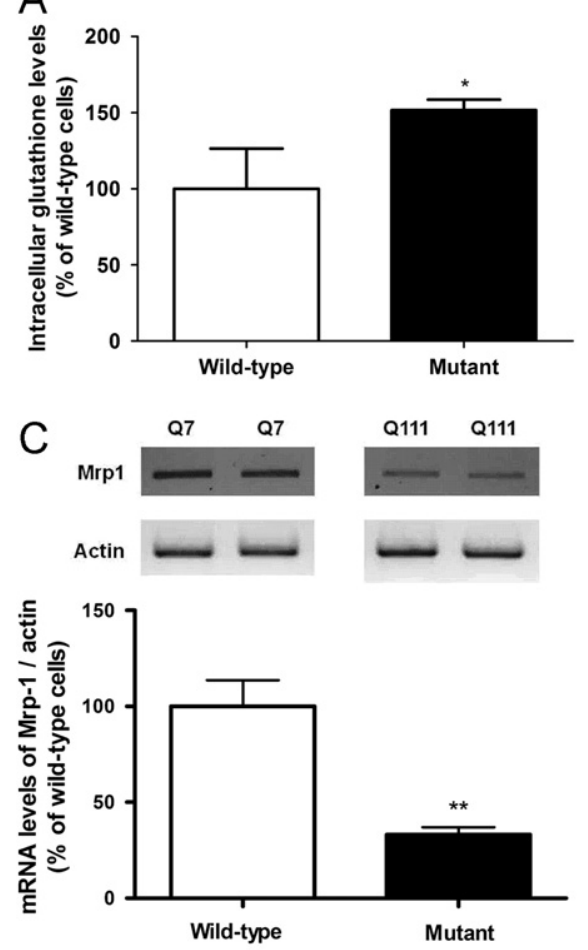

$E$
B

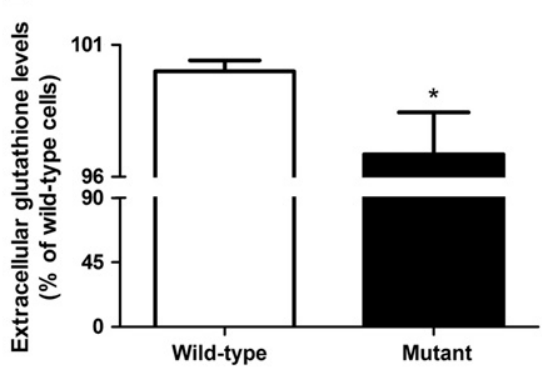

D

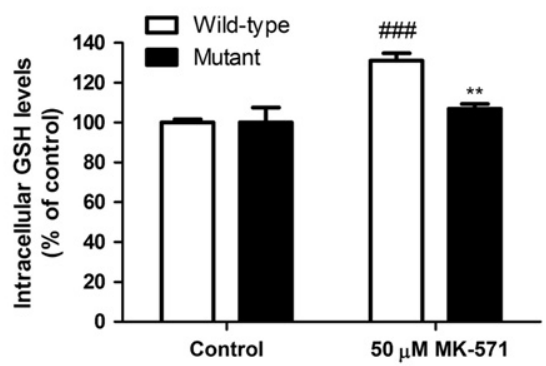

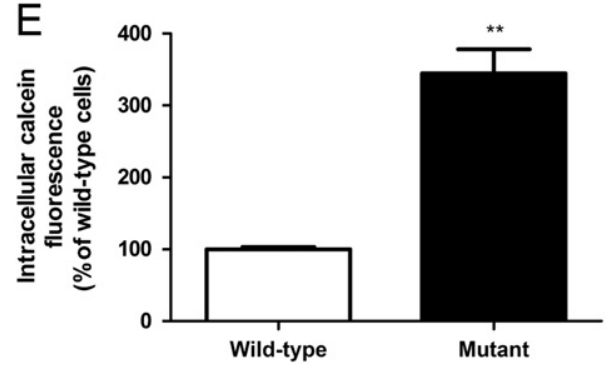

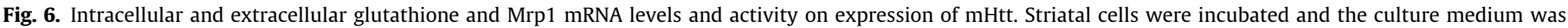

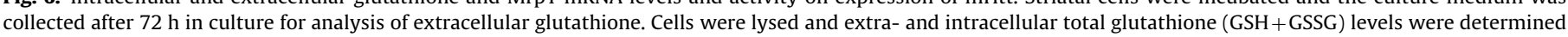

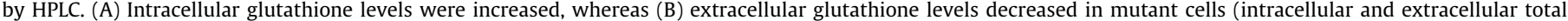

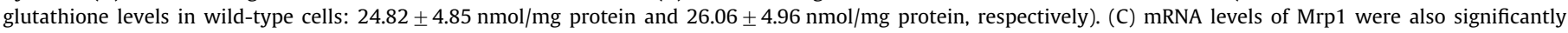

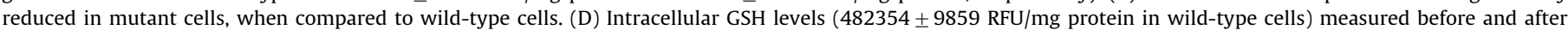

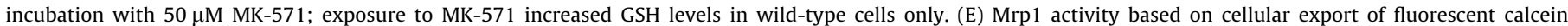

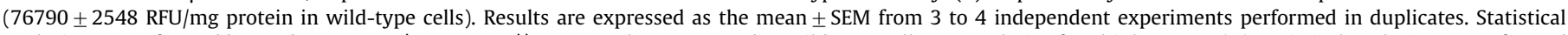

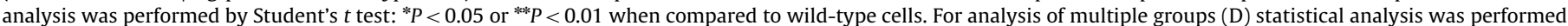

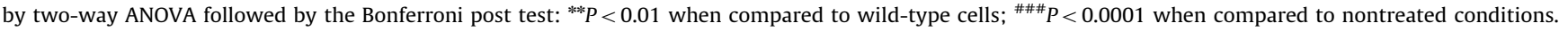

decreased GPx activity was found in erythrocytes of HD patients compared to control individuals [8], whereas in striatal tissue of R6/ 1 HD mice GPx activity was not different [26], and GPx transcription was unaltered in R6/2 HD mice [36], compared with wild-type mice. Concordantly with our study, an increase in GRed activity was found in erythrocytes from HD patients, compared to control individuals [37] and increased GRed transcription was found in the basal ganglia of R6/2 HD mice [36], suggesting a repository mechanism of GSH levels. We also observed increased activity of NADPH-producing enzymes of the pentose-phosphate pathway (G6PD and 6PGD), which is relevant since NADPH is an important cofactor of GRed. Indeed, NADPH levels were significantly increased in striatal mutant cells (data not shown), which may explain the higher activity of GRed. Changes in G6PD activity in HD models are controversial. G6PD activity was found to be increased in erythrocytes from HD patients [37], but decreased in the striatum from R6/2 mice [16]. Moreover, hexokinase, a prime enzyme in glycolysis and in the pentose-phosphate pathway upstream G6PD, was found to be actively increased in the brain of 3-NP-treated and in the HD transgenic N171-82Q mouse models [38].

Despite decreased GSH synthesis in HD striatal cells, we show that glutathione was accumulated intracellularly; this was not explained by alterations in GST or $\gamma$-GT (both involved in glutathione metabolism), since their activities were increased in mutant cells. Conversely, increased intracellular glutathione could be due to decreased release of the endogenous antioxidant to the extracellular milieu by Mrp1, which mediates the export of GSH and GSH conjugates in an ATP-dependent manner [25,39], thus also requiring a functional metabolic status of the cells. Mrp1 is a $190-\mathrm{kDa}$ protein involved in cellular xenobiotics metabolite detoxification, namely carcinogens, pesticides, herbicides, or metalloids. Mrp1 is highly overexpressed in many drug-resistant tumor cell lines and expressed at moderate levels in most normal tissues. In the brain it is part of the drug permeability barrier between the blood and the cerebrospinal fluid [40]. No data describing the Mrp1 involvement in HD have been reported until now. Here, we show that mRNA levels of Mrp1 are decreased in mutant HD striatal cells, 
which may be related to the negative effects of mHtt on transcription regulation [41]. Indeed, mHtt interacts with and sequesters CBP (CREB-binding protein, a coactivator of transcription that forms a complex with cAMP response-element (CRE) binding protein (CREB) to initiate gene transcription [42]) within protein aggregates [43], and decreases the activity of PGC- $1 \alpha$ (peroxisome proliferator-activated receptor- $\gamma$ coactivator $1 \alpha$ ), a transcriptional regulator of mitochondrial biogenesis and antioxidant enzymes (e.g., [44]). By directly interacting with transcription factors or coactivators, mHtt represses normal cellular transcription activity and thus may modify normal Mrp1 expression.

In astrocytes, Mrp1 was previously reported to mediate $60 \%$ of the GSH export and to be exclusively responsible for GSSG export [45]. Moreover, due to its role in the transport of glutathione-Sconjugates and GSSG into the extracellular space, proteins of the Mrp family may play an important function in defense mechanisms against oxidative stress [46]. Concordantly with the decreased expression of Mrp1, we observed that Mrp1 activity is affected in mutant cells. Furthermore, we observed a significant increase in intracellular GSH levels in wild-type cells, but not in mutant striatal cells after inhibition of Mrp1 with MK-571, largely evidencing the dysfunction in this transport protein in HD cells. No changes of intracellular GSH levels were observed in mutant cells, reinforcing the hypothesis of decreased Mrp1 function on expression of FLmHtt. In this perspective, mHtt or its fragments may also directly affect the activity of Mrp1, as depicted in the graphical abstract, although more studies will be required to test this hypothesis.

In summary, our results show that striatal cells expressing FL-mHtt exhibit raised antioxidant defense profiles through increased activity of the glutathione redox cycle and related metabolic enzymes, namely GST and $\gamma-\mathrm{GT}$, despite decreased GSH synthesis. Interestingly, our work gives evidence that decreased expression and activity of Mrp1 result in decreased release of glutathione, leading to its intracellular accumulation. Although this is apparently insufficient to prevent oxidative stress and apoptotic features, it may result from an attempt of HD striatal cells that do not exhibit massive cell death or visible mHtt aggregates to counterbalance initial generation of ROS evoked by FL-mHtt.

\section{Acknowledgments}

This work was supported by projects PTDC/SAU-FCF/66421/2006 and PTDC/SAU-FCF/108056/2008, funded by Fundação para a Ciência e a Tecnologia (FCT), Portugal, and co-financed by 'COMPETEPrograma Operacional Factores de Competitividade' QREN, and the European Union (FEDER-Fundo Europeu de Desenvolvimento Regional). M.R. was supported by the FCT Ph.D. fellowship SFRH/BD/ 41285/2007, T.C.-O. by the FCT postdoctoral fellowship SFRH/BPD/ 34711/2007, and T.R.R. by the FCT postdoctoral fellowship SFRH/ BPD/44246/2008, co-financed by 'POPH-Programa Operacional Potencial Humano', QREN, and the European Union.

\section{Appendix A. Supporting information}

Supplementary data associated with this article can be found in the online version at http://dx.doi.org/10.1016/j.freeradbiomed.2012. 09.004.

\section{References}

[1] Gil, J. M.; Rego, A. C. Mechanisms of neurodegeneration in Huntington's disease. Eur. J. Neurosci 27:2803-2820; 2008. [Erratum: Eur. J. Neurosci. 28:2156; 2008.].
[2] The Huntington's Disease Collaborative Research Group. A novel gene containing a trinucleotide repeat that is expanded and unstable on Huntington's disease chromosomes. Cell 72:971-983; 1993.

[3] Ferrante, R. J.; Kowall, N. W.; Beal, M. F.; Martin, J. B.; Bird, E. D.; Richardson, E. P. Jr. Morphologic and histochemical characteristics of a spared subset of striatal neurons in Huntington's disease. J. Neuropathol. Exp. Neurol. 46:12-27; 1987

[4] Browne, S. E.; Bowling, A. C.; MacGarvey, U.; Baik, M. J.; Berger, S. C.; Muqit M. M.; Bird, E. D.; Beal, M. F. Oxidative damage and metabolic dysfunction in Huntington's disease: selective vulnerability of the basal ganglia. Ann. Neurol. 41:646-653; 1997.

[5] Browne, S. E.; Ferrante, R. J.; Beal, M. F. Oxidative stress in Huntington's disease. Brain Pathol. 9:147-163; 1999.

[6] Stoy, N.; Mackay, G. M.; Forrest, C. M.; Christofides, J.; Egerton, M.; Stone, T. W.; Darlington, L. G. Tryptophan metabolism and oxidative stress in patients with Huntington's disease. J. Neurochem. 93:611-623; 2005.

[7] Goswami, A.; Dikshit, P.; Mishra, A.; Mulherkar, S.; Nukina, N.; Jana, N. R. Oxidative stress promotes mutant huntingtin aggregation and mutant huntingtin-dependent cell death by mimicking proteasomal malfunction. Biochem. Biophys. Res. Commun. 342:184-190; 2006.

[8] Chen, C. M.; Wu, Y. R.; Cheng, M. L.; Liu, J. L.; Lee, Y. M.; Lee, P. W.; Soong, B. W.; Chiu, D. T. Increased oxidative damage and mitochondrial abnormalities in the peripheral blood of Huntington's disease patients. Biochem. Biophys. Res. Communun 359:335-340; 2007.

[9] Panov, A. V.; Gutekunst, C. A.; Leavitt, B. R.; Hayden, M. R.; Burke, J. R.; Strittmatter, W. J.; Greenamyre, J. T. Early mitochondrial calcium defects in Huntington's disease are a direct effect of polyglutamines. Nat. Neurosci. 5:731-736; 2002

[10] Polidori, M. C.; Mecocci, P.; Browne, S. E.; Senin, U.; Beal, M. F. Oxidative damage to mitochondrial DNA in Huntington's disease parietal cortex. Neurosci. Lett. 272:53-56; 1999.

[11] Hersch, S. M.; Gevorkian, S.; Marder, K.; Moskowitz, C.; Feigin, A.; Cox, M.; Como, P.; Zimmerman, C.; Lin, M.; Zhang, L.; Ulug, A. M.; Beal, M. F.; Matson, W.; Bogdanov, M.; Ebbel, E.; Zaleta, A.; Kaneko, Y.; Jenkins, B.; Hevelone, N.; Zhang, H.; Yu, H.; Schoenfeld, D.; Ferrante, R.; Rosas, H. D. Creatine in Huntington disease is safe, tolerable, bioavailable in brain and reduces serum $80 \mathrm{~Hz}^{\prime} \mathrm{dG}$. Neurology 66:250-252; 2006

[12] Bogdanov, M. B.; Andreassen, O. A.; Dedeoglu, A.; Ferrante, R. J.; Beal, M. F. Increased oxidative damage to DNA in a transgenic mouse model of Huntington's disease. J. Neurochem. 79:1246-1249; 2001.

[13] Sorolla, M. A.; Reverter-Branchat, G.; Tamarit, J.; Ferrer, I.; Ros, J.; Cabiscol, E. Proteomic and oxidative stress analysis in human brain samples of Huntington disease. Free Radic. Biol. Med. 45:667-678; 2008

[14] Lim, D.; Fedrizzi, L.; Tartari, M.; Zuccato, C.; Cattaneo, E.; Brini, M.; Carafoli, E. Calcium homeostasis and mitochondrial dysfunction in striatal neurons of Huntington disease. J. Biol. Chem. 283:5780-5789; 2008.

[15] Tkac, I.; Dubinsky, J. M.; Keene, C. D.; Gruetter, R.; Low, W. C. Neurochemical changes in Huntington R6/2 mouse striatum detected by in vivo $1 \mathrm{H}$ NMR spectroscopy. J. Neurochem. 100:1397-1406; 2007.

[16] Choo, Y. S.; Mao, Z.; Johnson, G. V.; Lesort, M. Increased glutathione levels in cortical and striatal mitochondria of the R6/2 Huntington's disease mouse model. Neurosci. Lett. 386:63-68; 2005.

[17] Trettel, F.; Rigamonti, D.; Hilditch-Maguire, P.; Wheeler, V. C.; Sharp, A. H.; Persichetti, F.; Cattaneo, E.; MacDonald, M. E. Dominant phenotypes produced by the HD mutation in STHdh(Q111) striatal cells. Hum. Mol. Genet 9:2799-2809; 2000.

[18] LeBel, C. P.; Ischiropoulos, H.; Bondy, S. C. Evaluation of the probe $2^{\prime}, 7^{\prime}-$ dichlorofluorescin as an indicator of reactive oxygen species formation and oxidative stress. Chem. Res. Toxicol. 5:227-231; 1992.

[19] Hissin, P. J.; Hilf, R. A fluorometric method for determination of oxidized and reduced glutathione in tissues. Anal. Biochem. 74:214-226; 1976.

[20] Paglia, D. E.; Valentine, W. N. Studies on the quantitative and qualitative characterization of erythrocyte glutathione peroxidase. J. Lab. Clin. Med. 70:158-169; 1967.

[21] White, C. C.; Viernes, H.; Krejsa, C. M.; Botta, D.; Kavanagh, T. J. Fluorescencebased microtiter plate assay for glutamate-cysteine ligase activity. Anal. Biochem. 318:175-180; 2003.

[22] Zhu, Y: Carvey, P. M.; Ling, Z. Age-related changes in glutathione and glutathione-related enzymes in rat brain. Brain Res. 1090:35-44; 2006.

[23] Dogan, A. L.; Legrand, O.; Faussat, AM.; Perrot, JY.; Marie, JP. Evaluation and comparison of MRP1 activity with three fluorescent dyes and three modulators in leukemic cell lines. Leuk. Res. 28:619-622; 2004.

[24] Whiteman, M.; Rose, P.; Siau, J. L.; Cheung, N. S.; Tan, G. S.; Halliwell, B.; Armstrong, J. S. Hypochlorous acid-mediated mitochondrial dysfunction and apoptosis in human hepatoma HepG2 and human fetal liver cells: role of mitochondrial permeability transition. Free Radic. Biol. Med. 38:1571-1584, 2005.

[25] Müller, M.; Meijer, C.; Zaman, G. J.; Borst, P.; Scheper, R. J.; Mulder, N. H.; de Vries, E. G.; Jansen, P. L. Overexpression of the gene encoding the multidrug resistance-associated protein results in increased ATP-dependent glutathione S-conjugate transport. Proc. Natl. Acad. Sci. USA 91:13033-13037 1994.

[26] Perez-Severiano, F.; Santamaria, A.; Pedraza-Chaverri, J.; Medina-Campos, O. N.; Rios, C. Segovia, J. Increased formation of reactive oxygen species, but no changes in glutathione peroxidase activity, in striata of mice transgenic for the Huntington's disease mutation. Neurochem. Res. 29:729-733; 2004. 
[27] Milakovic, T.; Johnson, G. V. Mitochondrial respiration and ATP production are significantly impaired in striatal cells expressing mutant huntingtin. $J$ Biol. Chem. 280:30773-30782; 2005.

[28] Oliveira, J. M.; Chen, S.; Almeida, S.; Riley, R.; Goncalves, J.; Oliveira, C. R.; Hayden, M. R.; Nicholls, D. G.; Ellerby, L. M.; Rego, A. C. Mitochondrialdependent $\mathrm{Ca}^{2+}$ handling in Huntington's disease striatal cells: effect of histone deacetylase inhibitors. J. Neurosci. 26:11174-11186; 2006.

[29] Quintanilla, R. A.; Jin, Y. N.; Fuenzalida, K.; Bronfman, M.; Johnson, G. V. Rosiglitazone treatment prevents mitochondrial dysfunction in mutan huntingtin-expressing cells: possible role of peroxisome proliferatoractivated receptor-gamma (PPARgamma) in the pathogenesis of Huntington disease. J. Biol. Chem. 283:25628-25637; 2008.

[30] Tunez, I.; Drucker-Colin, R.; Jimena, I.; Medina, F. J.; Munoz Mdel, C.; Pena, J. Montilla, P. Transcranial magnetic stimulation attenuates cell loss and oxidative damage in the striatum induced in the 3-nitropropionic model of Huntington's disease. J. Neurochem. 97:619-630; 2006.

[31] Rosenstock, T. R.; de Brito, O. M.; Lombardi, V.; Louros, S.; Ribeiro, M.; Almeida, S.; Ferreira, I. L.; Oliveira, C. R.; Rego, A. C. FK506 ameliorates cell death features in Huntington's disease striatal cell models. Neurochem. Int. 59:600-609; 2011.

[32] Mao, Z.; Choo, Y. S.; Lesort, M. Cystamine and cysteamine prevent 3-NPinduced mitochondrial depolarization of Huntington's disease knock-in striatal cells. Eur. J. Neurosci 23:1701-1710; 2006.

[33] Beal, M. F.; Matson, W. R.; Storey, E.; Milbury, P.; Ryan, E. A.; Ogawa, T.; Bird, E. D. Kynurenic acid concentrations are reduced in Huntington's disease cerebral cortex. J. Neurol. Sci. 108:80-87; 1992.

[34] Klepac, N.; Relja, M.; Klepac, R.; Hecimovic, S.; Babic, T.; Trkulja, V. Oxidative stress parameters in plasma of Huntington's disease patients, asymptomatic Huntington's disease gene carriers and healthy subjects: a cross-sectional study. J. Neurol. 254:1676-1683; 2007.

[35] Sian, J.; Dexter, D. T.; Lees, A. J.; Daniel, S.; Agid, Y.; Javoy-Agid, F.; Jenner, P.; Marsden, C. D. Alterations in glutathione levels in Parkinson's disease and other neurodegenerative disorders affecting basal ganglia. Ann. Neurol. 36:348-355; 1994.
[36] Fox, J. H.; Barber, D. S.; Singh, B.; Zucker, B.; Swindell, M. K.; Norflus, F.; Buzescu, R.; Chopra, R.; Ferrante, R. J.; Kazantsev, A.; Hersch, S. M. Cystamine increases L-cysteine levels in Huntington's disease transgenic mouse brain and in a PC12 model of polyglutamine aggregation. J. Neurochem. 91:413-422; 2004

[37] Zanella, A.; Izzo, C.; Meola, G.; Mariani, M.; Colotti, M. T.; Silani, V.; Pellegata G.; Scarlato, G. Metabolic impairment and membrane abnormality in red cells from Huntington's disease. J. Neurol. Sci. 47:93-103; 1980.

[38] Olah, J.; Klivenyi, P.; Gardian, G.; Vecsei, L.; Orosz, F.; Kovacs, G. G. Westerhoff, H. V.; Ovadi, J. Increased glucose metabolism and ATP level in brain tissue of Huntington's disease transgenic mice. FEBS J. 275:4740-4755; 2008.

[39] Rappa, G.; Lorico, A.; Flavell, R. A.; Sartorelli, A. C. Evidence that the multidrug resistance protein (MRP) functions as a co-transporter of glutathione and natural product toxins. Cancer Res 57:5232-5237; 1997.

[40] Cole, S. P.; Deeley, R. G. Transport of glutathione and glutathione conjugates by MRP1. Trends Pharmacol. Sci. 27:438-446; 2006.

[41] Cha, J. H. Transcriptional dysregulation in Huntington's disease. Trends Neurosci. 23:387-392; 2000

[42] Mayr, B.; Montminy, M. Transcriptional regulation by the phosphorylationdependent factor CREB. Nat. Rev. Mol. Cell. Biol. 2:599-609; 2001.

[43] Steffan, J. S.; Kazantsev, A.; Spasic-Boskovic, O.; Greenwald, M.; Zhu, Y. Z.; Gohler, H.; Wanker, E. E.; Bates, G. P.; Housman, D. E; Thompson, L. M The Huntington's disease protein interacts with p53 and CREB-binding protein and represses transcription. Proc. Natl. Acad. Sci. USA 97:6763-6768; 2000.

[44] Cui, L.; Jeong, H.; Borovecki, F.; Parkhurst, C. N.; Tanese, N.; Krainc, D. Transcriptional repression of PGC-1alpha by mutant huntingtin leads to mitochondrial dysfunction and neurodegeneration. Cell 127:59-69; 2006.

[45] Minich, T.; Riemer, J.; Schulz, J. B.; Wielinga, P.; Wijnholds, J.; Dringen, R. The multidrug resistance protein 1 (Mrp1), but not Mrp5, mediates export of glutathione and glutathione disulfide from brain astrocytes. J. Neurochem. 97:373-384; 2006

[46] Keppler, D. Export pumps for glutathione S-conjugates. Free Radic. Biol. Med. 27:985-991; 1999 